\title{
Pre and Post Test Evaluations of Students in the Needs-Analysis Based EAP Course at Undergraduate Level
}

\author{
Zohreh Nafissi (Corresponding author) \\ Dep't of English Language and Literature, Faculty of Literature and Languages, Alzahra University, Vanak, Vanak Village St., Tehran, Iran \\ E-mail: z.nafisi@alzahra.ac.ir \\ Fariba Rezaeipanah \\ Dep't of English Language and Literature, Faculty of Literature and Languages, Alzahra University, Vanak, Vanak Village St., Tehran, Iran \\ E-mail: f_rezaeipanah@yahoo.com \\ Roya Monsefi \\ Azarbaijan Shahid Madani University, Tabriz, Iran \\ E-mail: monsefi_roya@yahoo.com
}

Doi:10.7575/aiac.alls.v.8n.1p.207

Received: 02/12/2016

URL: http://dx.doi.org/10.7575/aiac.alls.v.8n.1p.207

Accepted: 15/01/2017

\begin{abstract}
Iran's education system is exam-based and to gain admission to universities at undergraduate, graduate, and postgraduate levels, candidates have to sit a competitive examination. For this reason, developing an EAP course which prepares the candidates for these examinations is of crucial importance. The present study attempted to develop an EAP course for the selected number of undergraduate students of Statistics at Alzahra University and Shahid Beheshti University in Tehran. The aim was to prepare these students for the English language section of the entrance examination for MS degree in Statistics and then to determine if there was any significant difference between students' performance in their pre and post tests. Both quantitative and qualitative research methods were applied in this study and different instruments such as a questionnaire, semi-structured and structured interviews, and analysis of texts, were used to gather needs analysis data. The results indicated that the majority of participants preferred the presence of more ESP courses at universities. There was also a significant difference between pretest and posttest scores of the participants who took part in the EAP course.
\end{abstract}

Keywords: ESP, EAP Course, MS Entrance Examination, Needs Analysis, Study Purposes

\section{Introduction and Literature Review}

There has been a considerable dispute over the precise definition of ESP as a term. Even today there is much debate as to how to specify what exactly ESP constitutes (Brunton, 2009). Dudley-Evans and St. John (1998) attempted to apply a series of characteristics, some absolute and some variable, to settle the dispute over what ESP is (Dudley-Evans \& St. John, 1998, p. 4).

Absolute characteristics:

- $\quad$ ESP is defined to meet specific needs of the learners.

- $\quad$ ESP makes use of underlying methodology and activities of the discipline it serves.

- ESP is centered on the language (grammar, lexis, register), skills, discourse and genres appropriate to these activities.

Variable characteristics:

- $\quad$ ESP may be related to or designed for specific disciplines.

- ESP may use, in specific teaching situations, a different methodology from that of General English.

- ESP is likely to be designed for adult learners, either at a tertiary level institution or in a professional work situation. It could, however, be for learners at secondary school level.

- $\quad$ ESP is generally designed for intermediate or advanced students.

- Most ESP courses assume some basic knowledge of the language systems.

As noted by Gatehouse (2001), Dudley-Evans and St. John (1998) did not claim that ESP is necessarily in contrast with the General English.

Hutchinson and Waters (1987) mentioned that, two key historical periods breathed life into ESP. First, at the end of the Second World War an age of immense and unprecedented increase in scientific, technical and economic activity emerged on an international scale. This situation led the world to be dominated by two forces, technology and 
commerce, which in turn generated a demand for an international language. Consequently, English was established as the international language. Hence, demands for learning English rose considerably, because people realized that English played a pivotal role in the world of technology and commerce. The new generation of language learners had specific reasons and purposes for learning English. They were not learning English for the pleasure or prestige of learning a foreign language, rather they were learning it to fulfill their occupational or academic purposes. Another event contributing to this development was the Oil Crisis of the early 1970s which resulted in Western money and knowledge flowing into the oil-rich countries. As a result, the role of English was emphasized and constraints of time and money grew the demands for cost-effective courses with clearly explained goals.

The second key factor cited as having a tremendous impact on the emergence of ESP was a revolution in linguistics. Whereas traditional linguists set out to describe the formal features of language, revolutionary pioneers in linguistics began to focus on the use of language in real communication. One significant discovery was that "the language we speak and write varies considerably, and in a number of different ways from one context to another" (p.7). In other words, given the particular context in which English is used, the variant of English will change. This idea was taken one step further, "if language varies from one situation of use to another, it should be possible to determine the features of specific situations and then make these features the basis of the learners' course" (p.7).

According to Hutchinson and Waters (1987), since the purpose of ESP is to prepare learners to function adequately in target situations, the first step in designing an ESP course would be identifying the target situation and analyzing the linguistic features of that situation. Then these features will form the basis of the ESP syllabus. They called this process "needs analysis". As its name suggests, this type of needs analysis has to do with the strategies that learners employ in order to learn another language. This tries to establish how the learners wish to learn rather than what they need to learn (West, 1994).

Barnard and Zemach (2003) pointed out that there was no clear-cut distinction between ESP and EGP rather the boundaries were blurred. They went on to argue that ESP should not be considered as a separate division of English Language Teaching (ELT), however it is an area that has more focused courses in terms of aims and topics. Nevertheless, this does not imply that teaching ESP is the same as teaching general ELT. According to Basturkmen (2010) there are significant differences between teaching general ELT and ESP. She relied on Cook (2002) who distinguished between external and internal goals for language teaching. While external goals relate to the actual use of language outside the classroom, internal goals relate to educational purposes of the classroom. Being able to order a salad or provide technical information are examples of external goals, whereas being able to work in groups or having better attitudes towards speakers of other languages are instances of internal goals. Basturkmen (2010) believed that ESP mainly deals with external goals. She stated that "external goals suggest an instrumental view of language learning and language being learnt for non-linguistic goals. In a general ELT situation goals are generally linguistic" (p. 8). In other words, in an ESP situation learners want to attain real world objectives and they will become demotivated if they find course objectives irrelevant to their real world objectives. Finally, she argues that ESP largely concerns with language use while general ELT tends to focus on usage.

Dudley-Evans and St John (1998, p. 6) divided ESP into English for Academic Purposes (EAP) and English for Occupational Purposes (EOP). Two categories of EOP courses are often identified as English for Professional Purposes (EPP) and English for Vocational Purposes (EVP). The EPP includes English for Medical Purposes (EMP) and English for Business Purposes (EBP). The EVP includes Pre-Vocational English (PVE) and Vocational English (VE). Hutchinson and Waters (1987) noted that there was not a clear-cut distinction between EAP and EOP: "people can work and study simultaneously; it is also likely that in many cases the language learnt for immediate use in a study environment will be used later when the student takes up, or returns to a job" (p.16).

Established in the late 1970s as one of the two main branches of English for Specific Purposes, EAP can be defined as "English with the aim of assisting learners' study or research in that language" and covers "all areas of academic communicative practice" including pre-tertiary, undergraduate, and postgraduate teaching, tutor room/lecture hall interaction, academic written genres, and administrative practices (Hyland, 2006, p.1). Holme (1996) argues that every language syllabus is "selective" by nature. That is, even the General English syllabus is designed by having an understanding of the activities that learners will probably do in reality using English. Identifying these activities is the first step towards a needs analysis. "Consciously or unconsciously, therefore, all sensible course designers must begin by trying to assess students' specific needs. ESP is simply a narrowing of this needs spectrum” (p. 3).

McCarter and Jakes (2009) defined EAP as "the English that is taught to second-/third-language students preparing to enter undergraduate and postgraduate courses at universities and other institutions of higher education” (p.9). They further explained that students may also study at other levels like tertiary level, high-school level, technical colleges and private language schools. Or they may already be studying an academic course and receiving extra language support.

EAP approaches can be broken down into two core categories. These are English for General Academic Purpose (EGAP) and English for Specific Academic Purposes (ESAP) (Jordan, 1997). Where EGAP aims to isolate and teach skills/language thought to be common to all academic disciplines, focusing on 'study skills' (Jordan, 1997, p.7), ESAP is concerned with teaching skills/language related to one discipline, identifying course aims based on analysis of tasks that students will encounter in target situations (Hyland, 2006). In practical terms, there is no clear-cut distinction; rather ESAP and EGAP are at opposite ends of a continuum and courses fall somewhere between the two, although nowadays the trend seems to be towards ESAP as there is now clear evidence that academic discourses represent a variety of specific literacies (Hyland \& Hamp-Lyons, 2002). 
In the present study EAP refers to the English teaching which aims to prepare the undergraduate students of Statistics to take part in the entrance examination for MS degree in Statistics. Reviewing the related literature in Iran and other countries, Cowling (2007) employed multiple sources and methods in the needs analysis stage of developing a set of English language materials for an intensive course at a large Japanese company, which was intended to give students practical English language training focusing on language used in business situations. He concluded that great care should be taken in the syllabus design process and planning stages.

Venkatraman and Prema (2007) conducted a study to find out the English Language needs of engineering students at SASTRA University, India. In addition, the study was also aimed to discover the students' expectations regarding their English teachers. A needs survey was administered to 254 engineering students and it was found that these students had ranked listening (comprehension and scientific texts) and professional speaking skills (job interviews and group discussions) as the most required language skills and subskills. It was also reported that $98.9 \%$ of the students agreed that teachers of English in engineering colleges need a specific set of competencies, other than those of General English teachers. Based on the findings, the researcher proposed designing a modern curriculum in English and communication studies for engineering students and a competency-based training for English teachers in order to provide more audience-targeted instruction in EST.

Bosher and Smalkoski (2002) aimed to design a course in health-care communication for immigrant students in the United States. The fact that most of these students were not succeeding academically in the nursing program, motivated them to carry out this study. They used several procedures like observations, questionnaires and interviews and triangulated different sets of data from these sources to produce creditable results about the objective needs and necessities of the students, and then designed a course accordingly. They asserted that their course was successful because it responded to "the objective, subjective, and learning needs of ESL students in the A.S. degree nursing program" (p. 75).

Lepetit and Cichocki (2002) conducted a needs assessment study with university students who were preparing to work as health professionals. The results of their study emphasized that needs analysis is a potential and valuable source of information for designing curricula for health professionals based on learners' needs. Besides, the students identified three important need factors: "two distinct aspects of language skills and course contents - the written code and the oral code- and the place of study- an environment that places them in contact with native speakers" (p. 392).

In the Iranian context, Moslemi, Moinzadeh, and Dabaghi (2011) investigated the foreign language learning needs of MA students studying at the University of Isfahan. The results of their study revealed that the majority of the participants were dissatisfied with the current ESP courses for MA students. Giving more weight to English in the MA entrance examination and joint teaching of ESP courses were suggested as solutions to help students fulfill their English language needs at the MA level.

In another study, Rajabi and Azarpour (2011) explored the academic needs of business administration students at Malayer Islamic Azad University. Both qualitative and quantitative research methods were implemented, and 45 male students majoring in business administration took part in the study. The results indicated that developing speaking skills was more felt after graduation, whereas, developing reading skills was the key to students' success during their studies.

Khajavi and Gordani (2010) implemented questionnaires and semi-structured interviews to assess the language learning needs of MA students at Isfahan State University. They reported that, although speaking skill was rated very important by respondents, more than $70 \%$ of the students rated themselves poor or average in this skill. On the other hand, reading skill was considered as a skill that students felt more proficient at.

Eslami (2010) reported the perception that EAP students and instructors have of the problematic areas in EAP programs in Iran. A total of 693 EAP students majoring in different academic disciplines and 37 instructors participated in the study. The data incorporated respondents' perception of the importance of challenging areas in EAP programs. The results showed discrepancy between the perceptions of EAP learners in different academic fields and between learners and instructors. The results of the study revealed that students need to improve their general proficiency in English. Students' low level of language proficiency was believed to be more problematic by students in humanities and engineering than medicine. Inadequate vocabulary knowledge, slow reading pace, poor listening, speaking, writing and reading comprehension, and boring classes were among problematic areas for students.

Specialized English courses offered at universities in Iran mostly consist of reading passages related to the particular discipline, and translating them into Persian. However, in order to do well on the English section of entrance examination for MS degree, students need to master various skills and strategies which can help them become better readers. Apart from examinations, students need to take full advantage of English courses to be able not only to keep abreast of all the latest developments in their field but also to contribute to their field on a global scale. In other words, they need to develop the skills to read discipline-specific texts in English, be present at conferences, and translate the English texts into Persian.

It is acknowledged that "needs analysis is the cornerstone of ESP" and its proper application can result into a "focused course" (Dudley- Evans \& St John, 1998, p.121) which is actually sought for in this case. For this reason, an attempt is made to devise a framework for EAP course design which employs needs analysis as its starting point aiming to highlight the views of learners in the process of curriculum development, course and syllabus design, and evaluation of the effectiveness and efficiency of the implementation of the needs-based course. 
Given the paucity of research in needs analysis in the field of statistics, in the context of Iran, this study seeks to investigate the specific language needs of undergraduate students majoring in Statistics and to develop an EAP course accordingly, and to determine if there was any difference in the students' performance in the pre and post test. The first step would be conducting a needs analysis with the purpose of reaching a clear idea of the target needs and the learning needs of students. Needs analysis (also known as needs assessment) has an important role in the process of designing and carrying out any language course, whether it be English for Specific Purposes (ESP) or English for General Purposes (EGP), and its centrality has been confirmed by several researchers and authors (Dudley-Evans and St. John, 1998; Hutchinson and Waters, 1987; West, 1994;). This study can also be a contribution to English language syllabus design and course development.

The following questions were addressed in this study;

1. What are the students' views regarding the effectiveness of the EAP course offered by the researchers?

2. Is there any significant difference between the students' performance on the pretest (English section of the entrance examination for MS degree in Statistics, year 2009) and their performance on the post test (English section of the entrance examination for MS degree in Statistics, year 2015)?

\section{Method}

A convenience sample including the undergraduate students majoring in Statistics from Alzahra University and Shahid Beheshti University in Tehran was selected for the present study. The number of the students who took part in the EAP class was 20 and they had already passed general English course and ESP course. Prior to the commencement of the course the English section of a fairly recent version of the entrance examination for MS degree in Statistics (year 2009) was given to the participants of the course. The reason for choosing this version (year 2009), and not the earlier versions, was that from that year on, the reading comprehension passages have tended to be shorter in length. Therefore, this version resembled the latest versions of the exam. Then, at the end of the course of instruction, the English section of the latest version of the entrance examination for MS degree in Statistics (year 2015) was administered as the post test. There were 30 items on both the pretest and the post test; 10 vocabulary items, 5 grammar items, and 15 reading comprehension items, respectively. Almost 25 minutes was devoted to the process of answering each test. Finally, the results of the pretest were compared with the results of the post test, to see if the participants had made any progress.

As Dudley-Evans and St. John (1998) argued, one of the main sources for evaluation are the learners, and a useful method for collecting data for evaluation purposes is a questionnaire. At the end of the course, a course evaluation questionnaire was given to the participants in order to elicit their opinions regarding the effectiveness of the course. The questionnaire, which comprised of 14 Likert-scale items, was devised by the researchers in an attempt to spot the relative strengths and weaknesses of the course. The questions enquired about the efficacy of the instructor, the effectiveness of the course, the material, and etc. Most of the items (11 items) consisted of 5 point Likert scale, 1 item included 4 point Likert scale, and 2 items had 2 point Likert scales. Answering the questionnaire took about 10 minutes. The course evaluations questionnaire was completed by 20 students who had participated in the course. In order to check the reliability of the questionnaire, the Chronbach's Alpha internal consistency analysis was used which yielded a value of 0.85 , which is an acceptable value (Field, 2009).

Table 1. Reliability Statistics of the Course Evaluation Questionnaire

\begin{tabular}{llcr}
\hline & & $\mathrm{N}$ & \multicolumn{1}{c}{$\%$} \\
\hline Cases & Valid & 20 & 100.0 \\
& Excluded $^{\mathrm{a}}$ & 0 & .0 \\
& Total & 20 & 100.0 \\
\hline $\begin{array}{l}\text { a. Listwise deletion based on all variables in the } \\
\text { procedure. }\end{array}$ & & \\
\end{tabular}

Reliability Statistics

\begin{tabular}{|c|c|}
\hline $\begin{array}{c}\text { Cronbach's } \\
\text { Alpha }\end{array}$ & $\mathrm{N}$ of Items \\
\hline .854 & 14 \\
\hline
\end{tabular}

To answer the first research question, the data obtained from the course evaluation questionnaires was analyzed quantitatively using descriptive statistics including frequencies, and in order to answer the second research question, Wilcoxon signed-ranks test was applied to see if there was a significant difference between students' performance on the pretest and the post test. Since the data of this study violates one of the main assumptions of the $t$ test, which assumes that the samples are randomly and independently chosen from their populations, a nonparametric test called Wilcoxon signed-ranks test was used to compare the samples (Hinton, Brownlow, McMurray, \& Cozens, 2005). This 
test is the nonparametric equivalent of paired $t$ test, which is used when the samples are related (usually with the same participants in each sample).

\section{Results and Discussions}

3.1 Results and Discussions of the First Research Question

The first research question dealt with the students' views regarding the effectiveness of the EAP course offered by the researchers. In order to answer this question, the data obtained from the course evaluation questionnaire is presented here.

Table 2. Frequency of Responses to Course Evaluation Questionnaire Items in Likert Scale

\begin{tabular}{|c|c|c|c|c|c|}
\hline 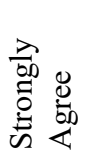 & 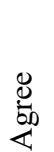 & 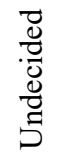 & 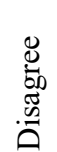 & 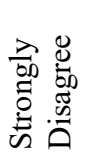 & $\sum_{\Sigma}^{\mathbb{\Xi}}$ \\
\hline
\end{tabular}

The instructor

demonstrated

knowledge of course materials.

The instructor was prepared for class.

The instructor was available outside of class.

The instructor stimulated interest in the course.

The instructor was responsive to students' needs and problems.

The course description accurately reflected the content of the course.

Reading passages were of reasonable length and level.

Learning materials were relevant and useful.

The material was well organized and presented.

The pace of the course was appropriate.

Overall, this course has stimulated my interest in this subject.
$40.0 \%$

$50.0 \%$

$10.0 \%$

$0.0 \%$

$0.0 \%$

4.30

0.657

$55.00 \%$

$10.0 \%$

$45.0 \%$

$30.0 \%$

$0.0 \%$

3.50

0.889

$15.0 \%$

$45.0 \%$

$30.0 \%$

$10.0 \%$

$0.0 \%$

3.65

0.875

$25.0 \%$

$55.0 \%$

$20.0 \%$

$0.0 \%$

$0.0 \%$

4.05

0.686

$60.0 \%$

$10.0 \%$

$0.0 \%$

$0.0 \%$

4.20

0.616

$$
55.0 \%
$$

$35.0 \%$

$10.0 \%$

$0.0 \%$

$0.0 \%$

4.45

0.686

$$
60.0 \%
$$

$5.0 \%$

$0.0 \%$

$0.0 \%$

4.55

0.605

$$
45.0 \%
$$

$50.0 \%$

$5.0 \%$

$0.0 \%$

$0.0 \%$

4.40

0.598

$15.0 \%$

$45.0 \%$

$5.0 \%$

$30.0 \%$

$5.0 \%$

3.35

1.226

$15.0 \%$

$45.0 \%$

$30.0 \%$

$10.0 \%$

$0.0 \%$

3.65

0.875 
Table 3. Frequency of Responses to Course Evaluation Questionnaire Items in Yes/No format

\begin{tabular}{|c|c|c|c|c|c|c|}
\hline & Yes & & No & Mean & & $\begin{array}{c}\text { Standard } \\
\text { Deviation }\end{array}$ \\
\hline $\begin{array}{l}\text { Do you think there } \\
\text { should be a } \\
\text { prerequisite for this } \\
\text { course? }\end{array}$ & $35.0 \%$ & & $65.0 \%$ & 1.65 & & 0.489 \\
\hline \multirow{2}{*}{$\begin{array}{l}\text { Would you take } \\
\text { another course with } \\
\text { this instructor? }\end{array}$} & \multicolumn{2}{|l|}{$85.0 \%$} & $15.0 \%$ & 1.15 & & 0.366 \\
\hline & $\begin{array}{c}\text { Very } \\
\text { Satisfied }\end{array}$ & Satisfied & $\begin{array}{c}\text { Fairly } \\
\text { Satisfied }\end{array}$ & $\begin{array}{c}\text { Not } \\
\text { Satisfied }\end{array}$ & Mean & $\begin{array}{c}\text { Standard } \\
\text { Deviation }\end{array}$ \\
\hline $\begin{array}{l}\text { Please rate your } \\
\text { overall } \\
\text { satisfaction with } \\
\text { this course. }\end{array}$ & $30.0 \%$ & $45.0 \%$ & $10.0 \%$ & $15.0 \%$ & 2.10 & 1.021 \\
\hline
\end{tabular}

The results revealed the strengths and weaknesses of the course. Most students were satisfied with the materials, the assignments, and the instructor. On the other hand, as it can be seen in the first table, a considerable percentage of students (about 35\%) were not satisfied with the pace of the course which is quite understandable since the course was rather short and intensive, and the instructor had to teach a considerable amount each session.

\subsection{Results and Discussions of the Second Research Question}

The second research question posed to determine if there was any significant difference between the students' performance on the pretest (English section of the entrance examination for MS degree in Statistics, year 2009) and their performance on the post test (English section of the entrance examination for MS degree in Statistics, year 2015). In order to answer this question, the means of scores of pretest and post test were compared. According to Hinton et al. (2005), in order to compare two samples, usually the $t$ test is used. However, the $t$ test relies on a number of assumptions. When the data does not meet the assumptions of the $t$ test, nonparametric equivalents of the $t$ test are used instead, which do not require these assumptions. Accordingly, for analyzing the data in this study, a nonparametric test called Wilcoxon signed-ranks test was used to compare the samples.

Table 4. Results of the Wilcoxon Signed-Ranks Test

\begin{tabular}{lrrrrr}
\hline & $N$ & Mean & Std. Deviation & Minimum & Maximum \\
\hline Pretest & 20 & 7.940 & 11.3287 & -11.1 & 31.1 \\
Posttest & 20 & 16.155 & 12.1290 & -3.3 & 38.9 \\
\hline
\end{tabular}

Ranks

\begin{tabular}{llrrr}
\hline & & N & Mean Rank & Sum of Ranks \\
\hline Posttest - Pretest & Negative Ranks & $4^{\mathrm{a}}$ & 4.25 & 17.00 \\
& Positive Ranks & $15^{\mathrm{b}}$ & 11.53 & 173.00 \\
\cline { 2 - 5 } & Ties & $1^{\mathrm{c}}$ & & \\
& Total & 20 & & \\
\hline
\end{tabular}
a. Posttest $<$ Pretest
b. Posttest $>$ Pretest
c. Posttest $=$ Pretest 
Test Statistics ${ }^{\mathrm{b}}$

\begin{tabular}{lr}
\hline & $\begin{array}{c}\text { Posttest - } \\
\text { Pretest }\end{array}$ \\
\hline$Z$ & $-3.140^{\mathrm{a}}$ \\
Asymp. Sig. (2- & .002 \\
tailed) & \\
\hline
\end{tabular}

a. Based on negative ranks.

b. Wilcoxon Signed Ranks Test

$[\mathrm{Z}=-3.140, N=19, p<0.01]$

From the test statistics table, it can be seen that $Z=-3.140$ and $p=0.002$, which is significant at $p<0.01$. From this it can be concluded that students' scores from the post test were significantly different from their scores from the pretest, and students had improved significantly. This suggests that the EAP course successfully achieved its primary purpose by improving students' test scores. Even though, the course was rather short and intensive, several factors contributed to its success. For instance, the syllabus adequately covered the pertinent topics and teaching materials were relevant and to the point. These, in turn, were the direct results of a careful needs analysis, which took learners' views into account.

\section{Conclusion}

Clearly, the role of needs analysis in any EAP course is indisputable, and its centrality has been acknowledged by several scholars (Dudley-Evans and St. John, 1998; Hutchinson and Waters, 1987; Johns, 1991; Jordan, 1997; West, 1994). Therefore, university and professional stakeholders must be politically and pedagogically aware of the importance of such needs assessments. As mentioned in the Introduction section, needs analysis is usually considered to be the foundation of the EAP process, so it must be conducted before the course is designed. Being aware of the needs of the learners influences not only the content of the language course but also what potential can be exploited through such course.

Moreover, the findings of this study suggested that the amount of time allotted to EAP courses in universities was not satisfactory, from students' point of view, and they expected to have EAP classes more frequently. For this reason, it is essential to give more room to EAP courses in the curriculum. The findings also indicated that getting better scores in the English section of the entrance examination for MS degree in Statistics was a high priority for the participants. Therefore, great care should be taken in preparing and selecting teaching material to ensure that students will be well prepared to take the exam.

It should be mentioned that, this study identified the English language needs as perceived by certain group of learners studying just at two universities, that is, Alzahra University and Shahid Beheshti University. Thus the results may not be generalizable to other educational settings or other groups of language learners with different backgrounds. However, it can be a sample of how the EAP needs are perceived in these two universities.

\section{References}

Barnard, R. and Zemach, D. (2003). Materials for specific purposes. In Brian Tomlinson (Ed.) Developing Materials for Language Teaching (pp. 307-323). Cambridge: Cambridge University Press.

Basturkmen, H. (2010). Developing courses in English for Specific Purposes. Palgrave: New York.

Bosher, S., \& Smalkoski, K. (2002). From needs analysis to curriculum development: Designing a course in health-care communication for immigrant students in the USA. English for Specific Purposes, 21(1), 59-79.

Brunton, M. (2009). An account of ESP - with possible future directions. English for Specific Purposes, 3 (24). Retrieved from

http://www.esp-world.info/Articles_24/An\%20account\%20of\%20ESP.pdf

Cook, V. J. (2002). Language teaching methodology and the L2 user perspective. In V. J. Cook (Ed.), Portraits of the L2 User. Clevedon: Multilingual Matters

Cowling, J. D. (2007). Needs analysis: Planning a syllabus for a series of intensive workplace courses at a leading Japanese company. English for Specific Purposes, 26(4), 426-442.

Dudley-Evans, T., \& St. John, M.J. (1998). Developments in English for Specific Purposes: A multi-disciplinary approach. Cambridge: Cambridge University Press.

Eslami, Z. (2010). Teachers' voice vs. students' voice: A needs analysis approach to English for Academic Purposes (EAP) in Iran. English Language Teaching. 3(1), 3-11.

Field, A. (2009). Discovering statistics using SPSS. London: SAGE.

Gatehouse, K. (2001). Key issues in English for specific purposes (ESP) curriculum development. The Internet TESL Journal, 7(10). Retrieved from http://iteslj.org/Articles/Gatehouse-ESP.html 
Hinton, P. R., Brownlow, C., McMurray, I. \& Cozens, B. (2005). SPSS explained. London, New York: Routledge.

Holme, R. (1996). ESP ideas. Harlow, Essex: Longman.

Hutchinson, T., \& Waters, A. (1987). English for specific purposes: A learning-centered approach. Cambridge: Cambridge University Press.

Hyland, K. (2006). English for Academic Purposes: An advanced resource book. New York: Routledge.

Hyland, K., \& Hamp-Lyons, L. (2002). EAP: Issues and directions. Journal of English for Academic Purposes, 1(1), 112 .

Johns, A. M. (1991). English for specific purposes (ESP): Its history and contributions. In M. Celce-Murcia (Ed.), Teaching English as a second or foreign language (pp. 67-77). Boston: Heinle \& Heinle.

Jordan, R.R. (1997). English for academic purposes: A guide and resource book for teachers. Cambridge: Cambridge University Press.

Khajavi, Y., \& Gordani, Y. (2010). Investigation of Iranian MA students' perceptions of their academic English language needs, abilities, and problems. English for Specific Purposes World, 31(10).

Lepetit, D., \& Cichocki, W. (2002). Teaching languages to future health professionals: A needs assessment study. Modern Language Journal, 86(3), 384-396.

Mccarter, S. \& Jakes, P. (2009). Uncovering EAP: How to teach academic writing and reading. Oxford: Macmillan Education.

Moslemi, F., Moinzadeh, A., Dabaghi, A. (2011). ESP needs analysis of Iranian MA students: A case study of the University of Isfahan. English Language Teaching, 4(4), 121-129.

Rajabi, P., \& Azarpour, N. (2011). Academic needs of Iranian business administration students in ESP classes. Contemporary Online Language Education Journal, 1, 20-32.

Venkatraman, G. \& Prema, P. (2007). English language skills for engineering students: A needs survey. ESP World, 3 (16). Retrieved from http.//www.espworld.info/contents.htm

West, R. (1994). State of the art article: Needs analysis in language teaching. Language Teaching, 27(1), 1-19. 